DOI: 10.32089/WBH.PHW.2020.4(274).0005

orcid.org/0000-0001-7211-1955

WOJCIECH PADUCHOWSKI

(Oddziałowe Biuro Badań Historycznych

Instytutu Pamięci Narodowej w Krakowie)

\title{
Jan Kotyza, zollnierz Armii Krajowej, Batalionów Chłopskich, ludowego Wojska Polskiego - zarys biograficzny
}

Jan Kotyza to bohater lokalnej historii ziemi krakowskiej, związany z rodzinnymi Bieńczycami, gdzie współtworzył życie społeczne; ukończył Uniwersytet Jagielloński, zdobywszy wykształcenie do nauczania wychowania fizycznego. Kotyza był żołnierzem Armii Krajowej (AK), Batalionów Chłopskich ${ }^{1}$ (BCh) oraz tzw. ludowego Wojska Polskiego (lWP), po zakończeniu wojny zaś działaczem katolickim przez wiele lat związanym z Kurią Metropolitalną w Krakowie. Już w okresie międzywojennym był znaną postacią w podkrakowskich wsiach - zwłaszcza tych położonych na wschód od miasta. Czuł się chłopem, ale nie był związany politycznie ani organizacyjnie z ugrupowaniami ludowymi. Jak sam twierdził, odrzucała go ich antyklerykalna postawa. Jan Kotyza pozostawił po sobie szerokie, w zdecydowanej większości niepublikowane ${ }^{2}$, wspomnienia obejmujące przede wszystkim okresy międzywojenny i okupacji niemieckiej. W dużej mierze na tej swoistej autobiografii bazuje niniejszy artykuł. Przy jego pisaniu wykorzystano również materiały

${ }^{1}$ Członkostwo w BCh traktuję jako służbę żołnierza i to niezależnie od tego, czy była to służba przed, czy po scaleniu z AK. Wynika to z semantycznego znaczenia słowa żołnierz de facto, tzn. odnosi się do faktycznych wykonywanych czynności związanych semantycznie $\mathrm{z}$ „zawodem” żołnierza, niezależnie od stosowania prawa międzynarodowego w tym zakresie. Jest to zgodne z teorią nauki Thomasa Kuhna dot. naukowości przypadków będących poza obecnym paradygmatem tego, co się uważa za naukowe, a co nie. Zob. m.in. A. F. Chalmers, Czym jest to, co zwiemy nauką?, tłum. A. Chmielewski, Wrocław 1993.

${ }^{2}$ J. Kotyza, Moje Bieńczyce [w:] Czas zatrzymany 2, t. 1: Wybór tekstów oraz fotografii $z$ terenów Nowej Huty i okolic, red. A. Gryczyński, Kraków 2008, s. 134-178. W tomie tym opublikowano wspomnienia Kotyzy z licznymi skrótami i opuszczeniami. 
z Archiwum Uniwersytetu Jagiellońskiego, Archiwum Miasta Krakowa, Centralnego Archiwum Wojskowego Wojskowego Biura Historycznego, Archiwum Katolickiego Stowarzyszenia Młodzieży oraz Archiwum Instytutu Pamięci Narodowej w Krakowie.

Jan Kotyza urodził się 7 stycznia 1909 r. w podkrakowskiej wsi Bieńczy$\mathrm{ce}^{3}$. Na jego postawę i wybory życiowe - jak sam podkreślał - niewątpliwie wpłynęło to, że urodził się w tej części Polski, będącej przecież pod zaborem, w którym mogło się rozwijać w miarę swobodnie życie narodowe. Nasiąkał więc od początku patriotyzmem - jego świadomość narodowa, jak i jego kolegów, była bardzo rozwinięta. Największy wpływ na to miała szkoła, w której nacisk kładziono na znajomość m.in. historii bohaterów narodowych. W momencie odzyskania niepodległości przez Polskę miał 9 lat - wiele lat później wspominał rozbrajanie w Krakowie austriackich żołnierzy, spośród których wielu było mieszkańcami podkrakowskich wsi.

Kotyza urodził się jako czwarte dziecko swoich rodziców. Mieszkali w małym drewnianym domu krytym strzechą, zajmując tylko część domu - izbę ok. 3 na 4 m. Ojciec Jana, Kacper, pracował w miejscowym młynie, który był własnością żydowskiej firmy Wasserberger i Spółka. Matka Katarzyna w tym czasie już nie pracowała zawodowo. W domu, oprócz zajmowania się dziećmi, dorabiała szyjąc. Wywodził się zatem z domu de facto robotniczego, gdzie podstawą utrzymania była praca najemna, choć rodzina kulturowo była zdecydowanie chłopska. Dziadek Jana, Maciej Kotyza, był zamożnym chłopem i wójtem we wsi, jednakże w większości roztrwonił majątek. Rodziny Kacpra i Katarzyny nie zaliczano do kategorii najbiedniejszych mieszkańców wsi (określanych mianami „dziadów” i „komorników”). Praca w młynie oraz szycie przynosiły taki dochód, że mogli sobie pozwolić na zakup 3/4 morgi (około 35 arów) pola, zaś w późniejszym czasie na kupno starego domu i zabudowań gospodarczych - aczkolwiek wymagało to pożyczki. Status rodziny we wsi wzrósł - nie bez znaczenia było bowiem to, że posiadała własny dom. Przeprowadzka do niego nastąpiła w roku 1913. Dom składał się z dwóch pomieszczeń mieszkalnych - „izdebki” oraz kuchni. W tej pierwszej spali rodzice, natomiast w kuchni wszystkie czworo dzieci na dwóch łóżkach ${ }^{4}$. Komfort życia rodziny polepszył się zdecydowanie. Sytuacja ta mogła się jednak szybko zmienić na gorsze. We wsi wybuchł wielki pożar, który strawił m.in. młyn. Na szczęście Kacper Kotyza z pomocą znajomego znalazł pracę jako dróżnik kolejowy na trasie Kraków-Kocmyrzów. Jego żona ze starszymi

\footnotetext{
${ }^{3}$ Archiwum Uniwersytetu Jagiellońskiego (dalej: AUJ), Teczki studenckie z lat 1927/281948/49, SWF 38/297, Kotyza Jan, Curriculum Vitae, Sambor 7 IX 1931 r., b.p.; W. Paduchowski, Nowa Huta nieznana i tajna, Kraków 2014, s. 215.

${ }^{4}$ J. Kotyza, „Od stycznia do września (1909-1939) - wspomnienia”, Kraków-Nowa Huta-Bieńczyce 1980, s. 3-19, mps. Niepublikowane wspomnienia Jana Kotyzy udostępnił autorowi jego syn - Andrzej Kotyza.
} 
synami zaczęła pracować na rogatce drogowej przy pobieraniu myta. Jan Kotyza w tym czasie, jako typowe wiejskie dziecko, zajmował się wypasem kóz i krów. Na początku roku 1917 sytuacja rodziny się zmieniła - Kacper Kotyza został zmobilizowany do armii austro-węgierskiej (początkowo ojciec Jana nie został powołany do armii ze względu na to, że był pracownikiem najpierw młyna, a następnie kolei, jednak wobec przedłużających się walk powołano w końcu i jego). W wojsku pozostawał do początku roku 1918, kiedy to ukończył 50 lat i z powodu wieku został zwolniony. Powrót ojca $\mathrm{z}$ wojny był wielkim świętem dla rodziny.

W roku 1915 Jan poszedł jako sześciolatek do szkoły powszechnej w Bieńczycach. Funkcjonowały tam cztery klasy, ale uczęszczało się do niej przez sześć lat. Po szkole pasał bydło oraz wieczorami robił w domu papierosy i w ten sposób pomagał w utrzymaniu rodziny. Nie zanosiło się więc, że będzie kontynuował naukę po skończeniu szkoły powszechnej. Przede wszystkim dzięki swojej wychowawczyni oraz rodzicom - którzy zdecydowali się posłać syna do gimnazjum, a był to spory wydatek dla rodziny (koszt czesnego i dojazdu) - Jan Kotyza kontynuował naukę . Trafił do Gimnazjum im. Jana III Sobieskiego w Krakowie. Na młodego gimnazjalistę duży wpływ wywarli uczący go profesorowie oraz - jak wspominał - rok 1923, gdy przez Kraków przeszła wielka fala strajków. Szczególnie zapamiętał wydarzenia z 6 listopada 1923 r., kiedy to doszło do starć pomiędzy robotnikami a wojskiem, w wyniku których padło wiele ofiar śmiertelnych po obu stronach, czego był naocznym świadkiem ${ }^{6}$. Po ukończeniu klasy piątej, która została rozwiązana ze względu na małą liczbę uczniów, został przeniesiony do Gimnazjum św. Jacka (od 1928 r. Gimnazjum im. Bartłomieja Nowodworskiego). Tamże chodził przez dwa lata do klasy VI. Wtedy też założył w Bieńczycach Stowarzyszenie Młodzieży Polskiej, którego został prezesem. W roku 1930 zdał maturę, mając 21 lat $^{7}$.

Po zdaniu matury został powołany do wojska. Służbę odbył najpierw w Szkole Podchorążych Rezerwy Piechoty nr 5 w Cieszynie (1930-1931), a następnie w 6 Pułku Strzelców Podhalańskich w Samborze (1931). Po zakończeniu służby był jeszcze kilkakrotnie powoływany na różnego rodzaju ćwiczenia rezerwy. Ostatni raz przed wojną odbywał ćwiczenia w okresie od 25 kwietnia do 4 czerwca 1938 r. w Ośrodku Wyszkolenia Rezerwy Piechoty w Różanie nad Narwią, jako dowódca kompanii w stopniu podporucznika ${ }^{8}$.

${ }^{5}$ Ibidem, s. 20-36.

${ }^{6}$ Zob. m.in. T. Marszałkowski, Zamieszki, ekscesy i demonstracje w Krakowie 1918-1939, Kraków 2006.

${ }^{7}$ AUJ, Teczki studenckie z lat 1927/28-1948/49, SWF 38/297, Kotyza Jan, Curriculum Vitae, Sambor 7 IX 1931 r., b.p.

${ }^{8}$ Archiwum Urzędu Miasta Krakowa (dalej: AUMKr), Akta personalne, 33/44 - Jan Kotyza, życiorys, odpis książeczki stanu służby oficerskiej, b.p. W 1933 r. mianowany 
Służbę wojskową traktował jak najbardziej poważnie. Jak sam stwierdzał, przykładał się do niej solidnie. Doświadczenie to niewątpliwie zaowocowało później w czasie pracy w pracy konspiracyjnej podczas okupacji niemieckiej.

Innym polem działalności Kotyzy było funkcjonowanie i szeroka działalność jako prezesa Katolickiego Stowarzyszenia Młodzieży Męskiej (KSMM) w Bieńczycach. Propagowało ono przede wszystkim katolicką myśl społeczną. $\mathrm{W}$ praktyce oznaczało to organizowanie na terenie wsi spotkań formacyjnych, różnorodnych wydarzeń kulturalnych - teatrów, jasełek, zabaw, festynów czy wydarzeń sportowych (piłka nożna, siatkówka, koszykówka, tenis stołowy, biegi) lub różnorakich kursów dokształcających, np. z zakresu rolnictwa. Tę działalność przerwała najpierw służba wojskowa, a następnie objęcie w 1937 r. posady instruktora w KSMM w Kielcach, gdzie pracował przez prawie cały rok 1937.

W latach 1931-1934 Kotyza kontynuował naukę w ramach trzyletniego Studium Wychowania Fizycznego UJ w Krakowie ${ }^{10}$. Nie zdołał on jednak $\mathrm{w}$ terminie obronić pracy magisterskiej, co nastąpiło dopiero w $1960 \mathrm{r}$., kiedy to napisał i obronił pracę pt. „Działalność Katolickiego Związku Młodzieży Męskiej na polu wychowania fizycznego na terenie zachodniej części województwa krakowskiego do roku 1939"11. Decyzję o podjęciu studiów z zakresu wychowania fizycznego podjął zapewne jeszcze w czasie pełnienia służby wojskowej w Samborze ${ }^{12}$. Jak sam wspominał, zastanawiał się, czy nie zostać zawodowym żołnierzem, ale ostatecznie wybrał studia. Pobierane nauki wykorzystywał zarówno w pracy zawodowej, jak i społecznej. Pracował m.in. w Okręgowym Urzędzie Wychowania Fizycznego i Przysposobienia Wojskowego (WFiPW) w Krakowie oraz jako instruktor (komendant) WF diecezjalnej centrali KSMM. Od początku czerwca 1939 r. objął posadę kierownika nowobudowanego Stadionu Miejskiego w Krakowie przy Al. 3 Maja. Nie był do końca przekonany co do tej decyzji, ale ostatecznie przeważył argument otrzymywania stałej pensji. Nowe stanowisko pracy podlegało pod Wydział Wojskowy Zarządu Miejskiego. Na stadionie

podporucznikiem, w 1932 r. 6 tygodni ćwiczeń rezerwy piechoty w Samborze jako dowódca plutonu; w 1934 r. 6 tygodni ćwiczeń rezerwy piechoty w 16 Pułku Piechoty (pp) w Tarnowie jako dowódca plutonu; w 1936 r. również odbywał ćwiczenia w Tarnowie. Zob. Centralne Archiwum Wojskowe Wojskowego Biura Historycznego (dalej: CAW-WBH), Kolekcja akt ujawnionych członków Armii Krajowej i Batalionów Chłopskich, 1530/73/144, Kotyza Jan s. Kaspra, Zeszyt ewidencyjny, b.p.

9 J. Kotyza, „Od stycznia do września...”, s. 37-87.

${ }^{10}$ AUJ, Teczki studenckie z lat 1927/28-1948/49, SWF 38/297, Kotyza Jan, Życiorys, b.m. 10 X 1958 r., b.p.

${ }^{11}$ http://biblioteka.awf.krakow.pl (dostęp 16 XI 2020).

${ }^{12}$ AUJ, Teczki studenckie z lat 1927/28-1948/49, SWF 38/297, Kotyza Jan, Curriculum Vitae, Sambor 7 IX 1931 r., b.p. 
znajdowały się takie urządzenia jak m.in. stadion lekkoatletyczny, amfiteatr czy basen, z którego w czasie gorącego lata korzystało około 2 tys. osób dziennie, (w tym także żołnierze czescy i słowaccy z utworzonego później Legionu Czechów i Słowaków oraz żołnierze 10 Brygady Kawalerii płk. Stanisława Maczka). Atmosfera w Krakowie od wiosny roku 1939 gęstniała coraz bardziej - mówiło się o możliwości wybuchu wojny. Kotyza wspominał, że będąc u kardynała Adama Stefana Sapiehy, którego zapraszał na dożynki, rozmawiał z nim na temat sytuacji międzynarodowej. Książę Sapieha miał powiedzieć, że społeczność żydowska twierdziła, że wojny być nie powinno; duża część społeczeństwa właśnie w taki sposób się pocieszała.

Przypadek sprawił, że Kotyza nie wziął udziału w kampanii polskiej 1939 r. W pewnym momencie dostał wezwanie do odbycia ćwiczeń wojskowych w 4 Pułku Piechoty (pp) stacjonującym w Kielcach. Gdyby udał się na owe ćwiczenia, zapewne wybuch wojny zastałby go w wojsku. Być może trafiłby nawet na Westerplatte, gdzie służyło 70 żołnierzy z 4 pp. Był jednak kierownikiem Stadionu Miejskiego i powołanie go do wojska skomplikowałoby prowadzenie na nim prac, dlatego też kierownik Okręgowego Urzędu WFiPW w Krakowie (który był jednocześnie członkiem komitetu budowy stadionu) wystarał się o odroczenie Kotyzie powołania na ćwiczenia do stycznia 1940 r. Nie musiał się też on stawić w wypadku ogłoszenia powszechnej mobilizacji. W dniu 6 sierpnia 1939 r. był świadkiem ostatniego zjazdu legionistów w Krakowie na którym marszałek Edward Śmigły-Rydz wygłosił słynne przemówienie: „Nie oddamy nie tylko sukmany, ale nawet guzika od niej"13. Miesiąc później w Krakowie byli już Niemcy.

1 września obudziły go wybuchy bomb. Niemieckie lotnictwo bombardowało lotnisko Rakowice-Czyżyny. Tak jak codziennie rano Kotyza udał się do Krakowa. W niedługim czasie rozpoczął się generalny exodus dużej części ludności na wschód. Również i Kotyza opuścił rodzinną wieś i udał się w kierunku Lublina. W momencie kiedy dotarła do niego informacja, że w Lublinie są już Niemcy, postanowił wracać do domu. Świadomość klęski powodowała, że - jak sam pisał - wszyscy zaczęli sobie zadawać pytanie: „No co teraz będzie, jak to będzie wyglądać nasze życie, kto będzie rządził, gdzie nasze wojsko?"14.

Okupacja niemiecka oznaczała dla Kotyzy koniec pracy na stadionie miejskim. Wydział Wojskowy, któremu podlegał w Zarządzie Miejskim Krakowa, został zlikwidowany. nie zwolniono go jednak z pracy - został przydzielony do nowo utworzonego Urzędu Kontroli Cen, gdzie kontrolował ceny w różnych sklepach $\mathrm{w}$ mieście. Po likwidacji instytucji został przydzielony do $\mathrm{V}$

${ }^{13}$ J. Kotyza, „Od stycznia do września...”, s. 149.

${ }^{14}$ Idem, „Od września do września 1939-1945 - wspomnienia”, Kraków-Nowa HutaBieńczyce 1982, s. 8. 
Urzędu Obwodowego mieszczącego się przy ul. Rakowickiej (takich urzędów obwodowych było w sumie sześć wraz z ich ekspozyturami), gdzie pracował w Ekspozyturze przy ul. Pasterskiej. Tam zajmował się kartami zapotrzebowania na odzież oraz sprawami meldunkowymi. Dzięki temu miał możliwość pomocy osobom, którym zależało na meldunku w Krakowie i otrzymaniu w ten sposób kenkarty (niem. Kennkarte) czyli niemieckiego dokumentu tożsamości. W międzyczasie musiał się zarejestrować jako były oficer rezerwy Wojska Polskiego - w ten sposób Niemcy gromadzili informacje o osobach potencjalnie dla nich niebezpiecznych. 1 września 1943 r., został najpierw zawieszony, a następnie zwolniony z Zarządu Miejskiego ${ }^{15}$. Powodem było wykrycie dokonywanych przez niego fałszerstw. Sprawa skończyła się dla Kotyzy dość szczęśliwie, bo nie został wydany w ręce Niemców.

W 1942 r. ożenił się z Marią Halik, z którą znał się z działalności w stowarzyszeniach katolickich. Razem zamieszkali w domu teścia, Wojciecha Halika. Do listopada 1943 r. Kotyza pozostawał bez pracy - zajmował się gospodarstwem. Przez pewien czas mógł czuć się bezpieczny, ponieważ w urzędzie pracy - Arbeitsamcie - pracował jego znajomy Wiesław Paszyński, który w jakimś stopniu go chronił, jednak do czasu. Pod koniec 1943 r. Kotyza musiał podjąć pracę - padło na Monopol Tytoniowy w Czyżynach, który okazał się być najlepszym rozwiązaniem. Tamże pracował do wiosny 1944 r., kiedy to Niemcy zaciągnęli m.in. pracowników monopolu do budowania umocnień wojskowych. Kotyza po jednym dniu pracy postanowił, że ucieknie; a tym samym nie powrócił już do pracy w Czyżynach ${ }^{16}$.

Jednym z ważniejszych momentów w czasie okupacji dla Kotyzy, jak i innych jemu współczesnych, był moment upadku Francji w 1940 r. Jej klęska w wojnie z Niemcami była dla wszystkich wielkim, deprymującym szokiem. Tym mocniejszym, że wcześniej większość społeczeństwa czekała z nadzieją wiosny roku 1940, kiedy to spodziewano się energicznej reakcji aliantów w postaci ofensywy przeciw Niemcom. Te nadzieje wyrażały się w powiedzeniu: „Im słoneczko wyżej, to Sikorski bliżej”'17. Było to zjawisko typowe dla polskiego społeczeństwa w tamtym okresie. Szybki upadek Francji spowodował też całkowicie odmienne postrzeganie klęski 1939 r., która odtąd jawiła się już w nieco innych barwach ${ }^{18}$.

${ }^{15}$ AUMKr, Akta osobowe, 33/44, Jan Kotyza, Przebieg służby w Zarządzie Miejskim, b.m., b.d., b.p.

${ }^{16}$ W Monopolu w Czyżynach pracował Volksdeutsch Józef Lokocz, który był postrachem wszystkich pracowników. Krążyły na jego temat plotki, że jego postawa wynikała z chęci kamuflowania jego powiązań z podziemiem. Zob. J. Kotyza, „Od września do września...”, s. 16.

${ }^{17}$ Ibidem, s. 24.

${ }^{18}$ Zob. szerzej J. Chrobaczyński, Compiègne 1940: klęska Francji w recepcji i postawach społeczeństwa polskiego, Kraków 2010. 
Bardzo ważnym wyborem w życiu Kotyzy była decyzja o zaangażowaniu się w działalność konspiracyjną. O ile samo postanowienie, czy angażować się, czy nie, było dla niego dość oczywiste ze względu na wyznawane poglądy i wartości, to profil tej działalności nastręczał trudności samemu Kotyzie. Prawdopodobnie miał poczucie nie do końca spełnionego obowiązku - jako oficer i żołnierz nie wziął udziału w kampanii polskiej 1939 r. Skoro był oficerem rezerwy Wojska Polskiego, naturalną koleją rzeczy była dla niego konspiracja wojskowa.

Kontakt z konspiracją nawiązał za pośrednictwem znajomych z przedwojennego KSMM, w szczególności ks. Władysława Świżka, wikarego w parafii pw. Najświętszego Salwatora na krakowskim Zwierzyńcu. Rozprowadzał on konspiracyjne gazety i zaproponował Kotyzie pracę przy ich kolportażu. Ten z kolei zaproponował Helenie Cieślewicz, która administrowała dworem w Bieńczycach, przepisywanie tychże gazetek na maszynie. Niedługo potem spotkał innego księdza, Czesława Skarbka, wikarego w kościele św. Anny w Krakowie, który kolportował wydawany już na powielaczu, „Dziennik Polski”, którego rozprowadzaniem zajął się również Kotyza. To właśnie Skarbek skontaktował go z przedstawicielem Związku Walki Zbrojnej (ZWZ) - inż. Józefem Rosiewiczem ps. „Rodak”, komendantem obwodu krakowskiego ZWZ ${ }^{19}$, pochodzącym z Pleszowa. Kotyza złożył przed Rosiewiczem przysięgę, stając się żołnierzem ZWZ i przyjmując ps. „Krzemień”.

Pierwszym jego zadaniem było zorganizowanie plutonu na terenie wsi Bieńczyce, Krzesławice oraz Mistrzejowice. Jego bezpośrednim przełożonym był Stanisław Partyła z Luboczy ps. „Kosa”. Pierwszymi których Kotyza zaprzysiągł w ZWZ, byli: Władysław Bochenek z Krzesławic, Władysław Chwastek z Mistrzejowic oraz jego rodzony brat Piotr. Wszyscy oni walczyli w kampanii polskiej. Od Kotyzy dostali zadanie zorganizowania we własnych wsiach drużyn ZWZ. Oprócz nich zgromadził wokół siebie grupę byłych członków KSMM, a byli to: Eugeniusz Hajto, Jan Bochenek, Józef Osiadło, Juliusz Osiadło, Andrzej Świerczewski, Edward Zybura, Władysław Krawczyk (wszyscy z Bieńczyc), Stanisław Turek, Antoni Turek, Antoni Cygan (z Mistrzejowic) oraz z Krzesławic Władysław Walerian. Ostatecznie Kotyza został dowódcą placówki ZWZ Mogiła, która obejmowała trzy gminy: Mogiłę, Ruszcze i Węgrzce ${ }^{20}$.

Przez ręce Kotyzy przechodziło wiele gazet konspiracyjnych o różnej proweniencji politycznej i ideowej. Był to przede wszystkim „Biuletyn Informacyjny”, ale też „Polska”, „Walka”, „Rzeczpospolita Polska”, „Tygodnik

${ }^{19}$ S. Pater, Nad ujściem Dlubni do Wisły, walka i męczeństwo podczas okupacji niemieckiej na terenie obecnej Nowej Huty w latach 1939-1945, Kraków-Nowa Huta 1989, s. 46.

${ }^{20}$ Ibidem. 
Polski" ${ }^{21}$. Przypadek sprawił, że do Kotyzy dotarła też prasa wydawana przez podziemny ruch ludowy, mianowicie ktoś dostarczył mu paczkę z ludowymi gazetami konspiracyjnymi, podpisaną „Krzemień”. Po przeprowadzonym "dochodzeniu” okazało się, że taki sam pseudonim nosił Jan Gajoch z Pleszowa ${ }^{22}$, który w tym czasie był przewodniczącym trójki powiatowej „Rocha”. Było to zaskoczenie dla Kotyzy. Wtedy jeszcze nie wiedział, że na terenie, na którym on działał, istnieje inna konspiracja. W późniejszym czasie sam stał się współtwórcą ludowego czasopisma „Ziemia”23.

Przed wojną Kotyza nie był związany z ruchem ludowym. Ustosunkowywał się do niego sceptycznie, a może nawet niechętnie. $Z$ dystansem odnosił się też do rodziny Ptaków z Bieńczyc, kojarzonej z tym kierunkiem ideowo-politycznym. Odrzucał antyklerykalizm i laickość, która traktowała obyczaje chłopskie tylko i wyłącznie jako folklor ${ }^{24}$. Jednakże przez długi okres był namawiany - zwłaszcza przez Walentego Adamczyka ps. „Topola”, „Granit” z Luboczy ${ }^{25}$ aby przeszedł z Armii Krajowej do Batalionów Chłopskich; Adamczyk zrobił to wcześniej i został pierwszym komendantem BCh na powiat krakowski ${ }^{26}$. W lecie 1942 r. doszło nawet do spotkania Kotyzy m.in. z komendantem BCh na Małopolskę i Śląsk, Narcyzem Wiatrem ps. „Zawojna”, który także go do tego namawiał. Usilne prośby ze strony BCh wynikały z tego, że w ich szeregach

${ }^{21}$ Zob. J. Jarowiecki, Konspiracyjna prasa w Krakowie w latach okupacji hitlerowskiej 1939-1945, Kraków 1980.

${ }^{22}$ Jan Gajoch ps. „Krzemień” (ur. 1900 w Pleszowie - zm. 1968 w Krakowie). Wybitny działacz ludowy. Uczestnik III Powstania Śląskiego. Przed II wojną światową prezes powiatowego i wiceprezes Wojewódzkiego Zarządu Związku Młodzieży Wiejskiej RP Wici w Krakowie. Prezes zarządu powiatowego Stronnictwa Ludowego (SL) w Krakowie. Przeciwnik polityczny rządów sanacyjnych, kilkukrotnie aresztowany. W czasie okupacji niemieckiej członek trójki politycznej Ruchu Oporu Chłopskiego (Roch). Współtwórca Batalionów Chłopskich oraz wydawanego w Mogile tygodnika „Ziemia”. Po wkroczeniu Armii Czerwonej aresztowany przez NKWD. Prezes powiatowego zarządu Polskiego Stronnictwa Ludowego (PSL) i wiceprezes Zarządu Wojewódzkiego PSL w Krakowie. Kilkukrotnie więziony przez Urząd Bezpieczeństwa (UB).

${ }^{23}$ S. Pater, Nad ujściem Dtubni..., s. 96.

${ }^{24}$ Odmiennie charakteryzują go Józef Marcinkowski i Alina Fitowa jako osobę sympatyzującą z ruchem ludowym. Zob. J. Marcinkowski, A. Fitowa, Ruch ludowy w Małopolsce i na Śląsk 1939-1945, Warszawa 1987, s. 448.

${ }^{25}$ Walenty Adamczyk, ps. „Topola”, „Granit” (ur. 1910 w Luborzycy - zm. 2003). W kampanii polskiej 1939 r. adiutant dowódcy 20 pp w Krakowie. Żołnierz ZWZ - dowódca kompanii w gminie Mogiła. W 1941 r. przeszedł do Straży Chłopskiej, po czym został komendantem BCh na powiat krakowski. W 1943 r. przeniesiony został do Miechowa jako inspektor Inspektoratu BCh „Chata”. Po scaleniu BCh z AK został zastępcą inspektora ds. informacji i propagandy Inspektoratu AK Miechów. Członek PSL, a następnie w SL. Inwigilowany przez policję polityczną.

${ }^{26}$ A. Fitowa, Bataliony Chłopskie w Małopolsce 1939-1945: działalność organizacyjna, polityczna i zbrojna, Warszawa-Kraków 1984, s. 481. 
brakowało oficerów. Sam Kotyza nie był pewien, co zrobić. Sytuacja zmieniła się dopiero jesienią 1942 r., kiedy to w dworze w Prusach doszło do spotkania przedstawicieli AK - m.in. komendanta obwodu Juliana Markowskiego ps. „Juliusz”, „Bończa” - z reprezentującymi ruch ludowy Janem Gajochem ps. „Krzemień”, Stanisławem Marsem ps. „Dąb” oraz Walentym Adamczykiem ps. „Topola”. Przedstawiciele AK zarzucali ludowcom, że ci przekonują żołnierzy AK, aby przyłączali do ruchu ludowego. Gajoch to potwierdził, jednak na swoje usprawiedliwienie dodał, że w jego opinii AK wtrącała się w sprawy polityczne, czego nie powinna robić. Chodziło tu o sprawę obsadzenia stanowiska Delegata Rządu RP na powiat krakowski, na co wpływ chciała mieć AK. Ludowcy uważali, że wojsko nie powinno wtrącać się do spraw politycznych. W czasie gorącej dyskusji Markowski oświadczył, że każde opuszczenie szeregów AK będzie traktowane jako dezercja ${ }^{27}$.

Sytuacja stała się katalizatorem potrzebnym do podjęcia decyzji przez Kotyzę. Według niego AK była powiązana z siłami politycznymi reprezentującymi tzw. sanacyjne rządy, do których odnosił się krytycznie. Niewątpliwie też całą sprawę odebrał bardzo emocjonalnie. Pomimo wcześniejszych wątpliwości postanowił, że jako syn chłopski przejdzie pod zwierzchność ruchu ludowego. Niedługo potem w mieszkaniu Jana Gajocha w Pleszowie złożył przyrzeczenie i stał się członkiem konspiracyjnego Stronnictwa Ludowego (SL) „Roch” i jednocześnie żołnierzem BCh. Wraz z Kotyzą do BCh przeszli wszyscy jego podkomendni, których było około 30. Paradoksalnie przejście Kotyzy i jego ludzi spowodowało, że proces scalenia BCh z AK na tym obszarze uległ przyspieszeniu.

W ramach BCh Kotyza przejął dowództwo nad żołnierzami z gmin Ruszcza, Mogiła i Zielonki. Po akcji scaleniowej z grupy tej utworzono batalion pod kryptonimem „Pająk”, który wszedł w skład obwodu Kraków-Powiat AK. Podporucznik Kotyza przyjął nowy pseudonim „Wiktor” - zapewne po to, aby nie mylono go z konspiracyjnym pseudonimem Jana Gajocha. W skład batalionu „Pająk” wchodziły 4 placówki/kompanie. Przy każdej kompanii, istniały patrole bojowe składające się z 10-15 żołnierzy. Większość żołnierzy BCh nie posiadała broni. Tę, którą mieli, musieli oddać dla tworzącej się Ludowej Straży Bezpieczeństwa (LSB). Na wiosnę 1943 r. ${ }^{28}$ Kotyza został mianowany przez Wiatra "Zawojnę" ${ }^{29}$ komendantem powiatowym BCh.

${ }^{27}$ W powiecie krakowskim pod koniec 1942 r. do BCh przeszli ze swoimi ludźmi prawie wszyscy oficerowie z gminy Mogiła. Byli to: wspomniany Walenty Adamczyk, Władysław Bochenek i Bolesław Raźny z Krzesławic, Bentkowski (imię nieznane) i Antoni Radziszewski z Luboczy oraz Józef Salwiński z Czyżyn; zob. A. Fitowa, Bataliony Chłopskie..., s. 121.

${ }^{28}$ Marcinkowski i Fitowa podają, że komendantem powiatowym BCh został we wrześniu 1943 r. Zob. J. Marcinkowski, A. Fitowa, Ruch ludowy..., s. 448.

${ }^{29}$ Narcyz Wiatr ps. „Zawojna” (ur. 1907 w Stróżach Niżnych - zm. 1945 w Krakowie). Przed II wojną światową aktywista ruchu ludowego. Więzień Berezy Kartuskiej. Żołnierz 
Powiat krakowski nosił kryptonim „Nadleśnictwo” nr 6. W skład komendy wchodzili, oprócz Kotyzy jako komendanta, Karol Koński - szef wywiadu, Teodor Cygan ps. „Czarny” - szef łączności, Wincenty Gajoch - kierownik kancelarii komendanta, Władysław Sterba - kierownik punktu łączności oraz Stanisław Augustynek jako kierownik punktu kontaktowego ${ }^{30}$.

Ostateczne scalenie BCh z AK na terenie powiatu krakowskiego dokonało się wiosną roku 1944. Jako komendant powiatowy BCh Kotyza został drugim zastępcą komendanta Obwodu Krakowskiego $\mathrm{AK}^{31}$ i jednocześnie nadal dowodził batalionem ps. „Pająk”. Pełniąc obowiązki komendanta powiatowego, stale uczestniczył w posiedzeniach tzw. trójki powiatowej „Rocha”. Uroczyste i symboliczne scalenie odbyło się 15 sierpnia $1944 \mathrm{r}$. w domu Antoniego Baranika w Mogile ${ }^{32}$. W czasie negocjacji scaleniowych ludowcy zaproponowali Antoniego Radziszewskiego, referenta prasowego batalionu „Pająk”, na redaktora akowskiego pisma „Placówka”, jednakże odrzucono tę propozycję ${ }^{33}$. Od czasu przejścia Kotyzy do BCh jego relacje z komendantem obwodu AK Kraków-Powiat Markowskim „Juliuszem”, nie układały się najlepiej. Według Kotyzy Markowski uważał go za „czerwonego” i tym samym niegodnego zaufania.

Jednym z zadań Kotyzy było uzbrojenie podległych mu oddziałów. Nie było to łatwe. „Wiktor” wspominał:

„[...] Z myślą o tym, by jednak mieć do dyspozycji jakąś choćby niewielką siłę bojową, postanowiłem z własnej inicjatywy powołać przy każdej Placówce [kompanii] patrol bojowy, który byłby jako tako uzbrojony, składał się z wartościowych ludzi i był możliwie operatywny. Patrole te służyły wyłącznie na rozkaz dowódcy batalionu i do zadań przez niego określonych. Przy Palcówce Bieńczyce był patrol dowodzony przez Eugeniusza Hajtę ps. "Gruszka». Przy Placówce Mogiła był patrol dowodzony przez Józefa Perlika ps. «Kruk», przy Placówce Batowice był patrol dowodzony przez Mariana Chorążego ps. «Gwint». Podobny patrol posiadała także Palcówka Kocmyrzów. Każdy z tych patroli liczył od 10 do 20 ludzi i był uzbrojony" 34 .

kampanii polskiej 1939 r. W czasie okupacji Niemieckiej komendant Okręgu Krakowskiego BCh. Po scaleniu BCh z AK zastępca komendanta Okręgu AK. 21 IV 1945 r. zastrzelony na krakowskich Plantach przez funkcjonariusza UB Stanisława Paryłę.

${ }^{30}$ S. Pater, Nad ujściem Dłubni..., s. 53.

${ }^{31}$ P. Sękowski, Polskie Stronnictwo Ludowe w Krakowie i powiecie krakowskim w latach 1945-1949, Warszawa 2011, s. 25; zob. również: A. Fitowa, Bataliony Chłopskie..., s. 201.

32 S. Pater, Nad ujściem Dtubni..., s. 65.

${ }^{33}$ A. Fitowa, Bataliony Chłopskie..., s. 201.

${ }^{34}$ Ibidem, s. 273-274. 
Aby uzbroić wyżej wymienione patrole, uciekano się czasami do rekwizycji mienia lub gotówki. Tak o tym wspominał Kotyza:

„Nie mieliśmy jako BCh żadnych środków na pracę konspiracyjną. Komenda AK nam nie dała, nawet po scaleniu, gdyż byliśmy zawsze niepewni i «czerwoni». «Roch» nie tylko nam nie dał, ale nawet przy formowaniu się BCh zabrał to, co było - np. broń dla LSB. Podobnie było, jeśli chodzi o jakieś instrukcje szkoleniowe czy bojowe. AK nam nie dawała, «Roch» zaczął dostarczać dość późno. Zmuszeni byliśmy starać się o wszystko we własnym zakresie. Chcąc czegoś dokonać, trzeba było mieć przede wszystkim broń. Coś zostało zdobyte na Niemcach. Myśleliśmy o kupnie. Ale pieniądze! Skąd wziąć pieniądze? Próbowaliśmy rekwizycji u zamożniejszych ludzi. Wywiad batalionu zbierał wiadomości o zamożniejszych gospodarzach i w ogóle mieszkańcach okolicy, którzy by mogli bez uszczerbku dać coś na pracę konspiracyjną. Po stwierdzeniu sytuacji majątkowej posyłaliśmy patrol bojowy z propozycją przekazania na cele konspiracyjne odpowiedniej kwoty, nie przekraczającej możliwości ofiarodawcy. Na ogół pieniądze były wpłacane bez większego sprzeciwu. Za te pieniądze zakupiono część broni i innych materiałów. Część pieniędzy zużyto na zapomogi dla niezamożnych, a nie mogących pracować żołnierzy i działaczy konspiracyjnych" 35 .

Zaangażowanie Kotyzy w działalność konspiracyjną nie miało miejsca jedynie na terenie powiatu krakowskiego. Był on również mobilnym inspektorem objazdowych kursów dywersyjnych. Powyższe przeprowadzał na Rzeszowszczyźnie, gdzie w swoim raporcie za okres od 5 września do 20 tegoż miesiąca 1943 r. opisywał uzbrojenie tamtejszych oddziałów BCh i LSB ${ }^{36}$. Wizytował też oddziały w Wieliczce, Skawinie, Rybnej oraz w Krzeszowi$\mathrm{cach}^{37}$. Natomiast na terenie rodzinnych Bieńczyc osobiście prowadził kurs podoficerski w domu Karola Hayty. Na program kursu składały się nauka o broni, zagadnienia z zakresu wyszkolenia bojowego i regulamin służby wewnętrznej. Po szkoleniu teoretycznym odbywały się ćwiczenia praktyczne $\mathrm{w}$ terenie. Kurs ten ukończyło ośmiu bechowców ${ }^{38}$. Od momentu przejęcia komendy powiatu krakowskiego BCh po Walentym Adamczyku Kotyza stale uczestniczył w posiedzeniach powiatowej trójki „Rocha”, w skład której

\footnotetext{
${ }^{35}$ Ibidem, s. 336.

${ }^{36}$ Ibidem, s. 340.

${ }^{37}$ J. Kotyza, „Od września do września...”, s. 45.

${ }^{38}$ A. Fitowa, Bataliony Chłopskie..., s. 356.
} 
wchodzili: przewodniczący Jan Gajoch „Krzemień”, komendant LSB Stanisław Mars „Dąb” oraz przewodniczący trójek gminnych ${ }^{39}$.

Zaangażowanie Kotyzy w działalność niepodległościową w podziemiu powodowało, że miał on kłopoty z utrzymaniem własnej rodziny - żony i małego dziecka. Oficerowie AK otrzymywali na ten cel fundusze, natomiast w BCh już nie. Nawet po scaleniu się BCh z AK Kotyza żadnego finansowego wsparcia nie otrzymywał. Dopiero w 1944 r. trójka powiatowa „Rocha” udzieliła mu pomocy pieniężnej. Miał pretensje zarówno do AK, jak i ludowców ${ }^{40}$.

Żołnierze BCh/AK będący pod dowództwem Kotyzy lub działający na jego terenie przeprowadzali wiele różnych akcji. Przede wszystkim było to karanie osób, które wysługiwały się Niemcom lub były zbyt gorliwe w wykonywaniu ich rozkazów - najczęściej była to kara chłosty. Zdarzały się również akcje specjalne, w ramach których likwidowano jednostki wybitnie zdemoralizowane, zarówno spośród Polaków, jak i Niemców. Kotyza w swoich wspomnieniach szczegółowo te akcje opisał.

Wykonawcami akcji likwidacyjnych były oddziały specjalne Franciszka Gawła ps. „Kotek” oraz Ludwika Sanoka ps. „Olek”, które działały na rozkaz Kierownictwa Walki Cywilnej/Kierownictwa Walki Podziemnej. Jedną z nieudanych tragicznych akcji była próba wykonania wyroku jesienią $1944 \mathrm{r}$. na Władysławie Ciepieli z Bieńczyc, zwanym „Ciupą”, który był znanym w okolicy złodziejem i bandytą. Pomyłkowo zastrzelono wtedy Wojciecha Bieronia z Krzesławic; Ciepiela uniknął śmierci ${ }^{41}$.

Wcześniej, w październiku 1943 r., wykonano wyrok na Andrzeju Chwai, sołtysie z Rybitw, za to że przekazał Niemcom informacje, na podstawie których wywieziono szereg osób do Rzeszy. W tym samym czasie zastrzelono, na podstawie wyroku, w Bodzanowie ks. Antoniego Skoczyńskiego, który wcześniej był wikarym w Luborzyckiej parafii i przyczynił się do pacyfikacji tamtejszej miejscowości, w wyniku której zginęło wielu ludzi. Za spowodowanie śmierci kilku osób zastrzelono również mieszkańca Grajowa (znajdującego się nieopodal Wieliczki), Antoniego Pajora ${ }^{42}$. Już przed wojną na terenie Mogiły byli znani z niecnych poczynań Feliks i Kazimierz Makułowie. W 1944 r. zamordowali oni w tejże miejscowości braci Jelonków. Oddział Franciszka Gawła „Kotka” ujął ich i rozstrzelał nad Wisłą, a ciała potopił. Powyższy oddział miał również wykonać wyrok - w tym samym dniu - na tzw. gra-

${ }^{39}$ Antoni Baranik z Mogiły, Wojciech Ziomek z Wadowa, Andrzej Bińczycki z Zielonek, Franciszek Piętak z Rusocic, Nazim (imię nieznane) z Skawiny, Walerian Naturski z Nawojowej Góry, Domoń (imię nieznane) z Przebieczan, Sandor (imię nieznane) z Brzegów oraz inni. Zob. J. Kotyza, „Od września do września...”, s. 45

\footnotetext{
${ }^{40}$ Ibidem, s. 55-56.

${ }^{41}$ Ibidem, s. 61.

${ }^{42}$ Ibidem, s. 65.
} 
natowym policjancie Jakubie Gwoździu za zabicie mieszkańca Krzesławic Józefa Kury, jednakże skazanemu udało się zbiec. Za to udało się, nie bez perturbacji, wykonać wyrok „Kotkowi” na jednym oficerze niemieckim, który znęcał się nad polskimi robotnikami, budującymi most na Wiśle w Nowym Brzesku $^{43}$. Z kolei w lipcu 1944 r. oddział Ludwika Sanoka wykonał wyrok śmierci na Marcinie Bednarzu z Pleszowa, niemieckim konfidencie ${ }^{44}$.

Za mniejsze przewinienia karano chłostą. W Zielonkach karę tę wymierzono tamtejszemu proboszczowi „za zbyt wysokie składki i ofiary na cele kościelne" ${ }^{\text {"45. }}$ W tej samej miejscowości chłostą ukarano Michała Barana za urządzanie przyjęć dla Niemców; takie samo wykroczenie popełnił dzierżawca dworu w Pleszowie Józef Szuba, którego wychłostano na oczach służby folwarcznej. Ukarano również: z tej samej miejscowości Tomasza Brodę za notoryczne pijaństwo; w Kantorowicach tamtejszego sołtysa za zbyt gorliwe wysługiwanie się Niemcom; w Krzesławicach wychłostano i ostrzyżono Stefanię Bieroń za zbyt zażyłe kontakty z Niemcami - oskarżył ją jej własny ojciec; z tej samej miejscowości ukarani zostali Antoni Cygan i Wiktoria Grymek za wysługiwanie się Niemcom oraz pijaństwo. Z innego powodu został wychłostany Piotr Grymek - mieszkaniec Krzesławic - nie przestrzegał on bowiem żałoby narodowej po Powstaniu Warszawskim, chodził po wsi i grał na harmonii. W Luboczy ukarano tamtejszą mieszkankę Zamojską, którą wychłostać musiał jej własny mąż, Feliks. Natomiast w Kujawach ukarano tamtejszego sołtysa Michała Cygana, również za fraternizowanie się z okupantem. Jak można zauważyć, bardzo często karano mieszkańców za pospolite pijaństwo. Nieprzypadkowo więc zlikwidowano również pięć bimbrowni w Pleszowie, Luboczy, Mogile, Łęgu oraz Krzesławicach. Ich właścicieli ukarano chłostą oraz grzywną. Przygodnych klientów również nie ominęła chłosta ${ }^{46}$.

$\mathrm{W}$ bezpośrednim kontakcie $\mathrm{z}$ dowódcą batalionu „Pająk” pozostawał patrol „Gruszki”. Wykonywał on różne zadania, np. wspomniane wyżej kary chłosty, czy też przeprowadzał rekwizycje. Patrol „Gruszki” m.in. przeprowadził akcję na Niemiecki Urząd Pracy w Sudole, zdobywając pistolet oraz maszynę do pisania. We wsi Dłubnia rozbroił niemieckiego żołnierza, zabierając mu broń długą i krótką. W Dzień Zaduszny jego żołnierze składali kwiaty na mogiłach pomordowanych przez Niemców ofiar w poaustriackim forcie w Krzesławicach ${ }^{47}$. Inny patrol, kierowany przez Józefa Perlika ps.

\footnotetext{
${ }^{43}$ Ibidem, s. 66.

${ }^{44}$ Ibidem, s. 67.

${ }^{45}$ Ibidem, s. 62.

${ }^{46}$ Ibidem, s. 63-64.

${ }^{47}$ Fort 49 „Krzesławice" był głównym miejscem egzekucji inteligencji polskiej z terenu Krakowa w trakcie Akcji AB.
} 
„Kruk”, wykonał akcję na dwór Volksdeutcha ${ }^{48}$ w Wadowie, rekwirując mu maszynę do pisania, pieniądze i inne potrzebne w konspiracji rzeczy. Inny z patroli zorganizował akcję przejęcia kilkunastu worków cukru z magazynów Monopolu Tytoniowego w Kocmyrzowie. Wszystkie patrole uczestniczyły w akcji rozlokowania wysiedleńców po powstaniu warszawskim, zmuszając niektórych niechętnych do przyjęcia warszawiaków ${ }^{49}$.

Czas okupacji niemieckiej to również udział Kotyzy w życiu społecznym rodzinnej miejscowości. Pomimo warunków okupacyjnych w Bieńczycach w roku 1941 tamtejsi mieszkańcy założyli sklep, którym zarządzała Spółdzielnia Spożywców „Bieńczycanka”. Inicjatywa ta pomagała miejscowej ludności zaopatrywać się w potrzebne produkty i jednocześnie przynosiła lokalnej społeczności dochód. Kotyza wszedł do jej zarządu i równocześnie był jej kierownikiem do roku 1942. Był nauczycielem tajnego nauczania w Bieńczycach, które odbywało się również w jego domu - nauczał geografii. Był Kotyza również sekretarzem bieńczyckiej delegatury Rady Głównej Opiekuńczej, gdzie zajmował się m.in. pomocą byłym mieszkańcom Warszawy, którzy również i w tych stronach znaleźli schronienie po powstaniu warszawskim ${ }^{50}$.

Wyzwolenie od Niemców i widok sowieckich żołnierzy, jak napisał, powitał $\mathrm{z}$ radością. 20 stycznia, $\mathrm{w}$ niedzielę, jak prawie wszyscy mieszkańcy Bieńczyc, poszedł do miejscowej kaplicy na Mszę Św., gdzie po raz pierwszy śpiewano „Ojczyznę wolną pobłogosław, Panie” ${ }^{11}$ - w niedalekiej przyszłości miało się okazać, że jego nadzieje na pełną wolność były płonne. W 1945 r. na krótko ponownie został kierownikiem spółdzielni. Oprócz tej pracy zaangażował się również w utworzenie w budynkach klasztornych Ojców Cystersów filii gimnazjum spółdzielczego, gdzie też sam nauczał. Gimnazjum zostało utworzone głównie dzięki staraniom Heleny Mierzwy, żony Stanisława Mierzwy ${ }^{52}$, która spędziła okupację w Mogile.

${ }^{48} \mathrm{Na}$ obecnym etapie badań nie udało się ustalić, czy zamieszkujący Dwór Badenich w Wadowie Wiktor Hoechsman przyjął którąś z kategorii narodowości niemieckiej.

${ }^{49}$ J. Kotyza, „Od września do września...”, s. 46-47.

${ }^{50} \mathrm{Na}$ temat tajnego nauczania w Bieńczycach oraz w całym powiecie krakowskim zob. S. Pater, Nad ujściem Dłubni..., s. 101; W. Choma, Informacja o tajnym nauczaniu w gminie Mogiła. Wspomnienie, „Roczniki Komisji Nauk Pedagogicznych” 1974, t. XVII, s. 115-123. Informacje o udziale Kotyzy w tajnym nauczaniu zawiera również Słownik biograficzny nauczycieli w Małopolsce w latach II wojny światowej (1939-1945), Ofiary wojny, żołnierze, działacze konspiracyjni, nauczyciele w jawnym i tajnym szkolnictwie, wstęp, oprac. i red. J. Chrobaczyński, Kraków 1996, s. 258.

${ }^{51}$ J. Kotyza, „Moje Bieńczyce II”, Kraków-Nowa Huta-Bieńczyce 1982, s. 83.

52 Stanisław Mierzwa (ur. 1905 w Biskupicach Radłowskich - zm. 1985 w Krakowie). W okresie międzywojennym m.in. wiceprezes Zarządu Wojewódzkiego SL, sekretarz Zarządu Okręgowego SL w Krakowie. Członek Rady Naczelnej SL, członek Naczelnego Komitetu Wykonawczego SL. Organizator strajków chłopskich, za co był więziony. W czasie okupacji niemieckiej członek okręgowego kierownictwa SL „Roch” na Małopolskę i Śląsk w Krakowie. 
Nowe komunistyczne władze wydały zarządzenie, w którym zobowiązywały oficerów rezerwy oraz zawodowych do zgłaszania się do rejestracji w najbliższych Rejonowych Komendach Uzupełnień (RKU). Wielu bojkotowało to zarządzenie i nie zgłaszało się, uznając, że nie mają do czynienia z polskim wojskiem. Inaczej postąpił Kotyza - stawił się w RKU Kraków już 8 lutego 1945 r. ${ }^{53}$ Uważał, że zgłoszenie się do tzw. ludowego Wojska Polskiego jest jego patriotycznym obowiązkiem. Już w kwietniu 1945 r. został powołany i wyjechał do Warszawy-Bielan do Ośrodka Szkolenia Oficerów Rezerwy, gdzie przeszedł szkolenie ${ }^{54}$. Wykłady prowadzili tam sowieccy oficerowie w polskich mundurach lub Polacy pochodzący ze wschodnich terenów II RP. Sowieci nie mówili po polsku, a tylko po rosyjsku - wówczas Kotyza nic nie rozumiał. Spośród wszystkich przebywających na ćwiczeniach rekrutowano żołnierzy do pułków zapasowych 2 Armii IWP. Owa rekrutacja odbywała się w dość specyficzny, ale typowy dla lWP, sposób. Mianowicie dwóch żołnierzy ubranych w Polskie mundury (Polak i Sowiet) indagowało oficerów stojących w szeregu o stosunki rodzinne kandydata. Pytano, gdzie się urodził, czym się zajmował jego ojciec i rodzeństwo. O ile z ojcem nie było problemów, bo był robotnikiem i z pochodzenia chłopem, to dwóch braci Kotyzy było przed wojną policjantami, co go początkowo zdyskwalifikowało. Faktycznie, bracia Józef i Stanisław Kotyza zginęli na terenie ZSRS - Józef zmarł w więzieniu NKWD w czerwcu 1945 r., natomiast Stanisław został zamordowany przez NKWD w Twerze w 1940 r. ${ }^{55}$ Nie wiemy jednak, czy w 1945 r. Kotyza wiedział o tych wydarzeniach..

Jak wspominał, wielu żołnierzy żałowało, że zgłosiło się do wojska ze względu na to, jak ich traktowano - np. straszono bronią, gdy ci nie chcieli się podporządkować. Jednakże 3 maja Kotyza znalazł się nieoczekiwanie w grupie około 250 oficerów skierowanych na front. Okazało się, że 2 Armia IWP wskutek fatalnego dowodzenia przez gen. Karola Świerczewskiego poniosła duże straty w bitwie pod Budziszynem i potrzebne były uzupełnienia ${ }^{56}$.

Członek centralnego kierownictwa ruchu ludowego, członek Rady Jedności Narodowej. Skazany w moskiewskim procesie 16 przywódców Polskiego Państwa Podziemnego. Współtwórca Polskiego Stronnictwa Ludowego (PSL), członek Naczelnego Komitetu Wykonawczego PSL, zastępca sekretarza generalnego PSL, wiceprezes zarządu wojewódzkiego PSL w Krakowie. Aresztowany przez UB i skazany na 10 lat więzienia w tzw. procesie krakowskim PSL i WiN (Wolność i Niezawisłość).

${ }^{53}$ CAW-WBH, Kolekcja akt ujawnionych członków Armii Krajowej i Batalionów Chłopskich, 1530/73/144, Kotyza Jan s. Kaspra, Zeszyt ewidencyjny, b.p.

${ }^{54}$ Przebywał tam w okresie 11 IV 1945 - 3 V 1945 r., zob. ibidem.

${ }^{55}$ J. Kotyza, „Moje Bieńczyce II”..., s. 104-105; www.muzeumkatynskie.pl (dostęp czerwiec 2018); www.katyn-pamietam.pl (dostęp czerwiec 2018).

${ }^{56}$ Zob. C. Grzelak, H. Stańczyk, S. Zwoliński, Armia Berlinga i Żymierskiego: Wojsko Polskie na froncie wschodnim 1943-1945, Warszawa 2009. 
Rozmowę mobilizującą przeprowadził z nimi sam Świerczewski, który wspominał im o ciężkich walkach. Kotyza został przydzielony do 28 pp 9 Dywizji Piechoty (DP) ${ }^{57}$. Z 9 DP powrócił z Drezna przez Wrocław do Rzeszowa. W walkach nie wziął jednak udziału. Będąc na terenach zamieszkałych przez Niemców, opisywał, jak żołnierze polscy wzorem sowieckich zabierali ze sobą zdobyczne trofea w postaci przede wszystkim zegarków. Tłumaczył ich zachowanie doznanymi wcześniej krzywdami.

Po przesunięciu dywizji w okolice Rzeszowa Kotyza uczestniczył w akcjach przeciwko Ukraińskiej Powstańczej Armii, przeczesując kompleksy leśne w pobliżu Sieniawy oraz wysiedlając ludność ukraińską do ZSRS. Wkrótce został zwolniony z wojska do cywila z powodu swego wykształcenia, tzn. nauczycielskiego (właśnie nauczycieli zwalniano) ${ }^{58}$. W październiku $1945 \mathrm{r}$. zweryfikowano go w stopniu kapitana ${ }^{59}$. Będąc dowódcą 6 kompanii 28 pp 9 DP w Łańcucie, dostał od dowódcy pułku i jego zastępcy do spraw polityczno-wychowawczych pochlebną opinię: „[...] Służbę wojskową traktuje poważnie i oddaje się jej z zamiłowaniem, dbały o żołnierza i lubiany przez niego. W stosunku do przełożonych lojalny. Politycznie wyrobiony"60.

Po powrocie do domu podjął pracę w szkole w Mogile - nauczał tam z przerwami do początku lat pięćdziesiątych, jednocześnie pracując w Referacie Duszpasterskim Kurii Metropolitalnej w Krakowie. Jesienią 1945 r. jako były żołnierz BCh wstąpił do powstającego Polskiego Stronnictwa Ludowego (PSL). Będąc działaczem tej partii, odwiedzał różne miejscowości i wygłaszał referaty - jak się wydaje, mocno się angażował w działalność stronnictwa. Świadczy o tym podjęcie przez Urząd Bezpieczeństwa (UB) inwigilacji jego

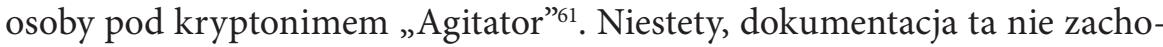
wała się. W ramach swojej partyjnej działalności - formalnie był członkiem komisji propagandowej Zarządu Powiatowego PSL - miał prowadzić prace na terenie gminy Mogiła ${ }^{62}$ Z ramienia PSL był także zastępcą członka komisji

${ }^{57}$ CAW-WBH, Kolekcja akt ujawnionych członków Armii Krajowej i Batalionów Chłopskich, 1530/73/144, Kotyza Jan s. Kaspra, Zeszyt ewidencyjny, b.p.

${ }^{58}$ W okresie maj 1945 - 15 VI 1945 r. dowódca plutonu w 28 pp 9 DP pod Dreznem. W okresie 15 VI 1945 - 22 IX 1945 dowódca kompanii oraz adiutant dowódcy batalionu 28 pp 9 DP w Łańcucie. Zdemobilizowany został 22 IX 1945 r. 20 X 1945 r. zweryfikowany w stopniu kapitana. Zob. CAW-WBH, Kolekcja akt ujawnionych członków Armii Krajowej i Batalionów Chłopskich, 1530/73/144, Kotyza Jan s. Kaspra, Zeszyt ewidencyjny, b.p. oraz J. Kotyza, „Od września do września...”, s. 117.

${ }^{59}$ CAW-WBH, Kolekcja akt ujawnionych członków Armii Krajowej i Batalionów Chłopskich, 1530/73/144, Kotyza Jan s. Kaspra, Zeszyt ewidencyjny, b.p.

${ }^{60}$ Ibidem.

${ }^{61}$ P. Sękowski, Polskie Stronnictwo Ludowe..., s. 110.

${ }^{62}$ Archiwum Instytutu Pamięci Narodowej w Krakowie (dalej: AIPN Kr), Wojewódzki Urząd Spraw Wewnętrznych w Krakowie (dalej: WUSW w Krakowie), 010/12056, Kotyza 
kontroli społecznej Gminnej Rady Narodowej w Mogile ${ }^{63}$. W niewyjaśnionych okolicznościach w $1946 \mathrm{r}$. został wyrzucony z PSL ${ }^{64}$. Sam w swoich wspomnieniach stwierdzał, że stało się tak z powodu działalności w KSMM.

W 1946 r. za namową ks. Mieczysława Noworyty - jednego z założycieli powojennego KSMM w archidiecezji krakowskiej ${ }^{65}$ - Kotyza zaangażował się ponownie w jego działalność. 13 kwietnia 1947 r. został wybrany za sprawą kard. Adama Stefana Sapiehy na prezesa tegoż stowarzyszenia w Krakowie. Działalność KSMM dotyczyła przede wszystkim kształtowania młodzieży na płaszczyźnie religijnej, kulturowo-oświatowej i sportowo-turystycznej ${ }^{66}$. Niewątpliwie Kotyza w ramach tej ostatniej wykorzystywał swoje wykształcenie do nauczania WF. Jako prezes opracowywał i wydawał periodyki stowarzyszenia „Młodzież Polska” oraz „Idziemy w życie”, które były główną podstawą do pracy w kołach stowarzyszenia. Póki było to jeszcze możliwe, podejmował w nich tematy marksizmu, czy też np. powstania warszawskiego ${ }^{67}$. W $1948 \mathrm{r}$. zetknął się z ks. Karolem Wojtyłą, który przybył jako wikariusz do Niegowici i angażował się w pracę formacyjną w ramach $\mathrm{KSMM}^{68}$. Działalność stowarzyszenia przypadła na bardzo trudny okres dla Kościoła katolickiego - władze z biegiem czasu coraz bardziej utrudniały jego funkcjonowanie. W niedługim czasie po wyrokach w procesie kurii krakowskiej ${ }^{69}-7$ lutego 1953 r. bp Franciszek Jop ${ }^{70}$ w obecności m.in. prezesa KSMM Jana Kotyzy rozwiązał stowarzyszenie wraz z działającym niejako obok niego Żywym

Jan, Doniesienie źródła ps. „Parabellum”, Kraków 30 I 1946 r., s. 105.

${ }^{63}$ P. Sękowski, Polskie Stronnictwo Ludowe..., s. 314.

${ }^{64}$ Według protokołu przesłuchania Kotyzy z 9 XII 1952 r. wyrzucony został z PSL za działalność w KSMM (sic!). Zob. AIPN Kr, WUSW w Krakowie, 010/12056, Kotyza Jan, Protokół przesłuchania podejrzanego, Kraków 9 XII 1952 r., s. 125

${ }^{65}$ T. Biedroń, Katolickie stowarzyszenia Młodzieży Męskiej w Krakowskiem 1945-1953, „Chrześcijanin w Świecie” 1985, nr 144/145 (wrzesień-październik), s. 73-74.

${ }^{66}$ Archiwum Zakładowe Katolickiego Stowarzyszenia Młodzieży w Krakowie (dalej: AZ KSM Kr.), Akta luźne „Młodzież Polska - okólnik KSMM w Krakowie”, maj 1947 r. T. Biedroń, Katolickie..., s. 79. AIPN Kr, WUSW w Krakowie, 010/12056, Kotyza Jan, protokół przesłuchania podejrzanego, Kraków 9 XII 1952 r., s. 125.

${ }^{67}$ AZ KSM Kr., Rocznica Powstania Warszawskiego, „Młodzież Polska - okólnik KSMM w Krakowie”, sierpień 1947 r. Marksizm i Katolicyzm, „Idziemy w życie - materiały do pracy w KSMM” 1947, nr 4.

68 „Tygodnik Powszechny” 1984, nr 11, [11 III 1984 r.].

${ }^{69}$ Był to proces pokazowy prowadzonym przeciw księżom z kurii krakowskiej, których fałszywie oskarżono o szpiegostwo na rzecz USA i Watykanu. Proces był jednym z elementów walki władz komunistycznych z Kościołem katolickim w Polsce. Zob. szerzej: M. Lasota, F. Musiał, Kościół zraniony: proces księdza Lelity i sprawa kurii krakowskiej, Kraków 2003.

${ }^{70}$ Franciszek Jop (ur. 1897 w Słupii Starej - zm. 1976 w Opolu). Od 1946 r. biskup. W okresie wypędzenia abp. Eugeniusza Baziaka wikariusz kapitulny archidiecezji krakowskiej. 
Różańcem Dziewcząt (ŻRD) wielu szykanom i inwigilacji ze strony UB. W 1952 r. został aresztowany przez UB sekretarz generalny KSMM ks. Mieczysław Noworyta ${ }^{72}$. Urząd Bezpieczeństwa przeprowadził w obecności Kotyzy rewizje w pomieszczeniach zajmowanych przez KSMM przy ul. Zwierzynieckiej 1 w Krakowie, rekwirując wiele dokumentów związanych z działalnością stowarzyszenia ${ }^{73}$. Administracja na polecenie urzędów bezpieczeństwa w zasadzie zabraniała organizacji wszelkich spotkań, akademii czy uroczystości ${ }^{74}$. Wobec takiej sytuacji bp Jop nie mógł inaczej postąpić, jak rozwiązać stowarzyszenie i tym samym nie narażać członków na kolejne represje.

Po rozwiązaniu KSMM Kotyza próbował podjąć pracę w Hucie im. Włodzimierza Lenina, jednak powiedziano mu, że z takim życiorysem nie dostanie żadnej pracy. W takiej sytuacji, jak się wydawało, jedną z możliwych opcji było podjęcie pracy w strukturach kościelnych. Kotyza rozpoczął pracę w kurii archidiecezji krakowskiej w wydziale/referacie duszpasterskim, którym kierował. Początkowo biuro wydziału znajdowało się przy ul. Zwierzynieckiej 1, gdzie zajmował się drukowaniem, przepisywaniem i kolportowaniem różnorodnych materiałów potrzebnych do pracy duszpasterskiej, w tym i dewocjonaliów - kiedy niemożliwe było drukowanie takowych, zlecał różnorakim osobom przepisywanie materiałów na maszynie. Byli to m.in. zatrudnieni w biurze Janina Bogdanowicz, Felicja Żukowska, Katarzyna Chomentowska, Zofia Makowska, Tadeusz Bigosz, Józef Knapik, Stanisław

${ }^{71}$ T. Biedroń, Kardynał Adam Stefan Sapieha a Katolickie Stowarzyszenia Młodzieży w Polsce 1945-1951, „Chrześcijanin w Świecie” 1989, nr 189 (czerwiec), s. 82. Na temat stowarzyszeń katolickich zob. T. Biedroń, Organizacje młodzieży katolickiej w Polsce w latach 1945-1953, Kraków 1991. Wobec uniemożliwienia przez władze komunistyczne rejestracji Katolickiego Stowarzyszenia Młodzieży Żeńskiej kardynał Adam Stefan Sapieha powołał Żywy Różaniec Dziewcząt.

${ }^{72}$ Mieczysław Noworyta (ur. 1906 - zm. 1980). W 1939 r. zastępca sekretarza generalnego KSMM w Krakowie, od 1945 r. sekretarz generalny. Więziony przez władze komunistyczne w związku z tzw. sprawą kurii krakowskiej. Zwolniony bez procesu. Władze uniemożliwiały mu objęcie probostwa. Ostatecznie został wysłany do Mszany Dolnej, gdzie w 1. 1958-1979 był administratorem i proboszczem tamtejszej parafii. Intensywnie inwigilowany przez UB/ SB. Zob. Leksykon duchowieństwa represjonowanego w PRL w latach 1945-1989, t. 3, pod red. J. Myszora, Warszawa 2006, s. 149-151.

${ }^{73}$ AIPN Kr, WUSW w Krakowie, 07/3424, t.1, Noworyta Mieczysław, Protokół rewizji, Kraków 6 XII 1952 r., k. 4.

${ }^{74}$ P. Mardyła, Duszpasterska troska Kościoła o wiernych wywodzacych się z Katolickiego Stowarzyszenia Młodzieży (1945-1989) [w:] Duszpasterstwa środowiskowe w latach 1945-1989, archidiecezja krakowska, red. C. Kuta, J. Marecki, Kraków 2014; P. Mardyła, Duszpasterstwo w czasach stalinowskich. Władze komunistyczne wobec działalności duszpasterskiej Kościoła rzymskokatolickiego w archidiecezji krakowskiej w latach 1945-1956, Kraków 2009; B. Karcz, Propozycja formacji społecznej młodzieży polskiej w programie i działalności reaktywowanego Katolickiego Stowarzyszenia Młodzieży, Kraków 2010, s. 33-48. 
Marcinkiewicz, Ludwik Mytkowicz. Wszystkie te osoby były związane wcześniej z KSMM i ŻRD ${ }^{75}$.

Według UB/SB Kotyza był wrogiem ustroju o silnym usposobieniu antykomunistycznym, przy tym zachowywał ostrożność - wiedział bowiem, że jest inwigilowany przez policję polityczną. W 1952 r. przesłuchiwało go UB w związku z aktywnością w czasie okupacji niemieckiej, choć zapewne nie był to jedyny powód. Po przesłuchaniu został zmuszony do podpisania oświadczenia, że będzie lojalnym obywatelem wykonującym wszystkie ustawy, zarządzenia i zalecenia władz państwowych ${ }^{76}$. Mimo to odmawiał uczestnictwa w zjazdach intelektualistów katolickich, które w rzeczywistości miały na celu rozbicie Kościoła w Polsce, z czego Kotyza zdawał sobie sprawę. Twierdził, że zjazdy były przygotowywane przez UB. Mówił, że Polska jest krajem komunistycznym, a nie - tak jak głoszono na wiecach - demokratycznym. „Figurant w codziennej swej działalności otwarcie wyrażał wrogi stosunek do wszelkich poczynań zachodzących w naszym kraju. Przez cały czas, jak stwierdza źródło «15» liczył na III wojnę światową, w wyniku której odzyskane zostaną ziemie wschodnie. Ze zdenerwowaniem odnosił się do poczynań USA, zarzucając im, że nie rozpoczynają wojny, gdy mają szansę zwycięstwa. Jak twierdził, tylko to może zmienić sytuację Kościoła w Polsce" 77 . Z drugiej strony obawiał się wybuchu wojny, ponieważ wiedział, że jako oficer rezerwy będzie musiał w niej uczestniczyć i walczyć po prze-

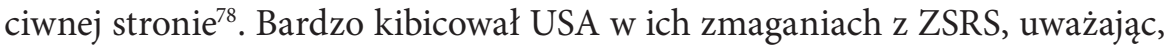
że podobnie myślących osób do niego w całej Polsce jest ok. 95\% ${ }^{79}$.

Okres stalinowski w życiu Kotyzy musiał na nim odcisnąć duże piętno. Znał bowiem z pewnością wiele osób, w tym księży, z kurii archidiecezji krakowskiej, która w tym czasie znalazła się na celowniku totalitarnego państwa. O inwigilacji jego osoby przez UB świadczą również wspomnienia Franciszka Szafrańca z Mogiły, który wspominał o tym w 2005 r. ${ }^{80}$ Sam Kotyza w swoich spisanych wspomnieniach nic na ten temat nie wspominał. Bardzo mało miejsca poświęcił swojemu życiu po 1945 r. Krytycznie odnosił się do tworzenia przez komunistów środowiska tzw. księży pa-

${ }^{75}$ AIPN Kr, WUSW w Krakowie, 010/12056, Kotyza Jan, doniesienie źródła ps. „15”, Kraków 16 VII 1954 r., s. 161; Doniesienie źródła ps. „15”, Kraków 30 VII 1954 r., s. 163.

${ }^{76}$ Ibidem, Oświadczenie, WUBP Kraków 20 X 1952 r., s. 122.

${ }^{77}$ Ibidem, Plan operacyjnych przedsięwzięć do sprawy operacyjnej obserwacji krypt. „PREZES” nr.rej.462/B p-ko, Kraków 28 X 1961 r., s. 86.

${ }^{78}$ Ibidem, Doniesienie źródła ps. „15”, [Kraków b.d.], s. 147. Jest to kolejny przykład życia wielu ludzi w tzw. psychologicznej przestrzeni społecznej w dychotomii pomiędzy wiarą i nadzieją, a strachem i lękiem. Szerzej zob. W. Paduchowski, Nowa Huta..., s. 153-188.

${ }^{79}$ AIPN Kr, WUSW w Krakowie, 010/12056, Kotyza Jan, Doniesienie źródła ps. „15”, Kraków 1 II 1954 r., s. 150; Doniesienie źródła „15”, Kraków 2 V 1954 r., s. 158.

${ }^{80} \mathrm{http}: / / \mathrm{nhmz} \cdot \mathrm{pl} / 3.4 /$ index.php? $\mathrm{dz}=$ wlasne\&pokaz_calosc\&id=6 (dostęp $4 \mathrm{~V}$ 2018). 
triotów i inteligencji katolickiej z nimi związanej. Przewidywał, że władza po rozprawieniu się z katolikami, którzy byli wrogo nastawieni do władzy ludowej, w następnym etapie zajmie się również i tymi, których ówcześnie uważała za "postępowych". Kotyza z racji miejsca pracy miał liczne znajomości z różnymi księżmi. Relacjonował ich postawy wobec wymuszonych na nich przysiąg, które musieli składać na wierność państwu. Bardzo często w prywatnych rozmowach z nim wyśmiewali ten akt - de facto bagatelizując go jako wymuszony pod presją ${ }^{81}$. Jednakże Kotyza rozumiał, że takie działanie władz rozbijało jedność Kościoła w Polsce i obawiał się, że komuniści będą mieli w tym zakresie pewne sukcesy. Zdawał sobie sprawę z fikcji różnego rodzaju zjazdów i kongresów, wiedząc, że wszystkie posunięcia i wystąpienia były starannie wyreżyserowane. W podobnym duchu wypowiadał się też o II zjeździe Polskiej Zjednoczonej Partii Robotniczej, po którym spodziewał się pogorszenia sytuacji robotnika i chłopa, a nie polepszenia, jak to głosiła propaganda ${ }^{82}$. Zdecydowanie uważał, że pomiędzy komunizmem/komunistami a Kościołem nie może być żadnej współpracy. Dowodem na to miała być ciągle pogarszająca się sytuacja Kościoła na skutek prześladowań przez władze. Uważał, że nadzieje tzw. postępowych katolików na jakieś porozumienie są całkowitą fikcją, ponieważ ostatecznym celem komunistów jest zniszczenie Kościoła. Jego zdaniem fakty takie jak m.in. usuwanie zakonników z ich dotychczasowych siedzib (Bernardyni z klasztoru w Alwerni) ${ }^{83}$, likwidacja religii w szkołach czy generalne usuwanie krzyży z miejsc publicznych były tego dowodem. Trzeźwo też oceniał sytuację międzynarodową. Nie widział w bliższej przyszłości możliwości zmiany ustroju w Polsce, choć jeszcze rok wcześniej liczył na wybuch wojny światowej, która wszystko miała zmienićs ${ }^{84}$. W tym czasie bowiem bardzo duża część społeczeństwa pokładała nadzieję w konflikcie między Wschodem a Zachodem w związku z wojną koreańską (1950-1953), co wiązało się z tzw. paniką wojenną ${ }^{85}$. Do globalnej wojny jednak nie doszło.

Powojenne życie Kotyzy było związane głównie z historią krakowskiego Kościoła. Obfitowało w różne doświadczenia i zwroty jak w roku 1956, czy też 1989. Historia ta wykracza jednak poza ramy niniejszego artykułu. Lata okupacji niemieckiej i czas tuż po wojnie to część życia Kotyzy przede

${ }^{81}$ AIPN Kr, WUSW w Krakowie, 010/12056, Kotyza Jan, Doniesienie źródła ps. „15”, Kraków 27 XI 1953 r., s. 140.

${ }^{82}$ Ibidem, Doniesienie źródła ps. „15”, Kraków 1 II 1954 r., s. 150.

${ }^{83}$ Zob. A. Mirek, Siostry zakonne w obozach pracy w PRL w latach 1954-1956, Lublin 2009.

${ }^{84}$ AIPN Kr, WUSW w Krakowie, 010/12056, Kotyza Jan, Doniesienie agenturalne źródła ps. „15”, b.m. 7 IX 1954 r., s. 170-171.

${ }^{85}$ D. Jarosz, M. Pasztor, W krzywym zwierciadle, Warszawa 1995, s. 144 i 148. 
wszystkim jako oficera/dowódcy, który pod swoją komendą miał ludzi dobrze sobie znanych jeszcze z czasów II RP. To pewnego rodzaju ciągłość trwania związków interpersonalnych, które przetrwały zmiany polityczne, społeczne i strukturalne. Osoby, z którymi współpracował na niwie partycypacji społecznej i kulturowej, stawały się potem żołnierzami czy to AK, czy BCh. Postać Kotyzy nie poddaje się też prostym kategoryzacjom. Dla niektórych może być jednostką wręcz kontrowersyjną - przejście z AK do BCh, potem ponowne scalenie z Armią Krajową, czy też wstąpienie do tzw. ludowego Wojska Polskiego. Niewątpliwie był on świadkiem i aktywnym uczestnikiem - w różnym zakresie - kilku epok. Poczynając od pamięci Polski pod zaborem austriackim (autonomia galicyjska), gdzie jego ojciec był żołnierzem C.K. armii, przez okres dwudziestolecia międzywojennego w wolnej Polsce; następnie najbardziej aktywny czas walki z okupantem w czasie II wojny światowej i kolejno okres PRL-u, aż po powstanie III RP.

\section{Bibliografia}

\section{Archiwalia}

Archiwum Uniwersytetu Jagiellońskiego

Teczki studenckie z lat 1927/28-1948/49

Archiwum Urzędu Miasta Krakowa

Akta personalne

Archiwum Zakładowe Katolickiego Stowarzyszenia Młodzieży w Krakowie

Akta luźne

Centralne Archiwum Wojskowe Wojskowego Biura Historycznego

Kolekcja akt ujawnionych członków Armii Krajowej i Batalionów Chłopskich

\section{Wspomnienia}

Kotyza J., Moje Bieńczyce [w:] Czas zatrzymany 2, t. 1: Wybór tekstów oraz fotografii z terenów Nowej Huty i okolic, red. A. Gryczyński, Kraków 2008.

\section{Wspomnienia niepublikowane}

Kotyza J., „Od stycznia do września (1909-1939) - wspomnienia”, Kraków-Nowa Huta-Bieńczyce 1980.

Kotyza J., „Od września do września 1939-1945 - wspomnienia”, Kraków-Nowa Huta-Bieńczyce 1982.

Kotyza J., „Moje Bieńczyce II”, Kraków-Nowa Huta-Bieńczyce 1982.

\section{Opracowania}

Biedroń T., Kardynał Adam Stefan Sapieha a Katolickie Stowarzyszenia Młodzieży w Polsce 1945-1951, „Chrześcijanin w Świecie” 1989, nr 189.

Biedroń T., Katolickie stowarzyszenia Młodzieży Męskiej w Krakowskiem 1945-1953, „Chrześcijanin w Świecie” 1985 (wrzesień-październik), nr 144/145. 
Biedroń T., Organizacje młodzieży katolickiej w Polsce w latach 1945-1953, Kraków 1991.

Chalmers A. F., Czym jest to, co zwiemy nauką?, tłum. A. Chmielewski, Wrocław 1993.

Choma W., Informacja o tajnym nauczaniu w gminie Mogiła. Wspomnienie. „Roczniki Komisji Nauk Pedagogicznych” 1974, t. XVII.

Chrobaczyński J., Compiègne 1940: klęska Francji $w$ recepcji i postawach społeczeństwa polskiego, Kraków 2010.

Fitowa A., Bataliony Chłopskie w Małopolsce 1939-1945: działalność organizacyjna, polityczna i zbrojna, Warszawa-Kraków 1984.

Grzelak C., Stańczyk H., Zwoliński S., Armia Berlinga i Żymierskiego: Wojsko Polskie na froncie wschodnim 1943-1945, Warszawa 2009.

Jarowiecki J., Konspiracyjna prasa w Krakowie w latach okupacji hitlerowskiej 1939-1945, Kraków 1980.

Jarosz D., Pasztor M., W krzywym zwierciadle, Warszawa 1995.

Karcz B., Propozycja formacji społecznej młodzieży polskiej w programie i działalności reaktywowanego Katolickiego Stowarzyszenia Młodzieży, Kraków 2010.

Lasota M., Musiał F., Kościół zraniony: proces księdza Lelity i sprawa kurii krakowskiej, Kraków 2003.

Marcinkowski J., Fitowa A., Ruch ludowy w Małopolsce i na Śląsku 1939-1945, Warszawa 1987.

Mardyła P., Duszpasterska troska Kościoła o wiernych wywodzacych się z Katolickiego Stowarzyszenia Młodzieży (1945-1989) [w:] Duszpasterstwa Środowiskowe w latach 1945-1989, archidiecezja krakowska, red. C. Kuta, J. Marecki, Kraków 2014.

Mardyła P., Duszpasterstwo w czasach stalinowskich. Władze komunistyczne wobec działalności duszpasterskiej Kościoła rzymskokatolickiego w archidiecezji krakowskiej w latach 1945-1956, Kraków 2009.

Marszałkowski T., Zamieszki, ekscesy i demonstracje w Krakowie 1918-1939, Kraków 2006.

Mirek A., Siostry zakonne w obozach pracy w PRL w latach 1954-1956, Lublin 2009.

Paduchowski W., Nowa Huta nieznana i tajna, Kraków 2014.

Pater S., Nad ujściem Dłubni do Wisty, walka i męczeństwo podczas okupacji niemieckiej na terenie obecnej Nowej Huty w latach 1939-1945, Kraków-Nowa Huta 1989.

Sękowski P., Polskie Stronnictwo Ludowe w Krakowie i powiecie krakowskim w latach 1945-1949, Warszawa 2011.

\section{Słowniki i leksykony}

Leksykon duchowieństwa represjonowanego w PRL w latach 1945-1989, t. 3, pod red. J. Myszora, Warszawa 2006.

Słownik biograficzny nauczycieli w Małopolsce w latach II wojny światowej (19391945). Ofiary wojny, żołnierze, działacze konspiracyjni, nauczyciele w jawnym i tajnym szkolnictwie, wstęp, oprac. i red. J. Chrobaczyński, Kraków 1996. 


\section{Prasa}

„Tygodnik Powszechny” 1984.

\section{Materiały internetowe}

http://biblioteka.awf.krakow.pl (dostęp 16 XI 2020).

http://nhmz.pl/3.4/index.php? dz=wlasne\&pokaz_calosc\&id=6 (dostęp 4 V 2018). www.katyn-pamietam.pl (dostęp czerwiec 2018). www.muzeumkatynskie.pl (dostęp czerwiec 2018).

\section{STRESZCZENIE}

\section{Wojciech Paduchowski, Jan Kotyza, żołnierz Armii Krajowej, Batalionów Chłopskich, ludowego Wojska Polskiego - zarys biograficzny}

Artykuł przedstawia zarys biografii Jana Kotyzy, żołnierza Armii Krajowej, Batalionów Chłopskich oraz ludowego Wojska Polskiego.

Urodził się w podkrakowskich Bieńczycach w rodzinie chłopskiej. Dzięki uporowi rodziców i nauczycieli ukończył gimnazjum, a następnie również Studium Wychowania Fizycznego przy Uniwersytecie Jagiellońskim. Tuż przed wybuchem II wojny światowej Kotyza objął posadę kierownika nowobudowanego stadionu miejskiego przy Alei 3 Maja w Krakowie. Był oficerem rezerwy, ale nie wziął udziału w kampanii polskiej 1939 r. W czasie okupacji zaangażował się w pracę konspiracyjną. Pierwotnie polegała ona tylko na kolportażu podziemnych pism. Przystąpił do Związku Walki Zbrojnej, przyjął ps. „Krzemień”. Początkowo organizował pluton na terenie wsi Bieńczyce, Krzesławice oraz Mistrzejowice. Następnie został komendantem placówki ZWZ Mogiła, która obejmowała terytorialnie gminy Mogiła, Ruszcza oraz Węgrzce. Z szeregów ZWZ przeszedł do Batalionów Chłopskich. Jednocześnie został członkiem konspiracyjnego Stronnictwa Ludowego „Roch”. Po scaleniu BCh z AK objął dowództwo batalionu krypt. „Pająk”. W 1943 r. awansował w ramach BCh i został komendantem powiatu krakowskiego krypt. "Nadleśnictwo nr 6”. W niedługim czasie po oswobodzeniu od Niemców zgłosił się na wezwanie nowych władz do tzw. ludowego Wojska Polskiego. Początkowo nie trafił na front, ostatecznie został wysłany do 2 Armii WP. Nie zdążył wziąć udziału w walkach z Niemcami - był pod Dreznem, skąd wycofano go przez Wrocław do Rzeszowa, gdzie brał udział w walkach z UPA. Po zdemobilizowaniu wrócił w rodzinne strony.

Słowa kluczowe: Jan Kotyza, Polskie Państwo Podziemne, ZWZ/AK, Bataliony Chłopskie, Ruch Ludowy, powiat krakowski, II wojna światowa, konspiracja, Bieńczyce, ludowe Wojsko Polskie 


\section{SUMMARY}

\section{Wojciech Paduchowski, Jan Kotyza, Soldier of the Home Army,} Peasants' Battalions, Polish People's Army - a Biographical Outline

The article presents a biographical outline of Jan Kotyza, a soldier of the Home Army, Peasants' Battalions and the Polish People's Army.

He was born in Bieńczyce near Cracow in a peasant family. Thanks to the persistence of his parents and teachers he finished high school and then studied physical education at the Jagiellonian University. Just before the outbreak of World War II, Kotyza took over the position of manager of the newly built city stadium at 3 Maja Avenue in Cracow. He was a reserve officer but did not take part in the Polish campaign of 1939. During the occupation he got involved in underground work. Initially, it consisted only in the distribution of underground magazines. He joined the Union of Armed Struggle (ZWZ) and took pseudonym „Krzemień”. Initially he organized a platoon in the villages of Bieńczyce, Krzesławice and Mistrzejowice. Then he became the commander of the ZWZ post „Mogił”, which included municipalities: Mogiła, Ruszcza and Węgrzce. He left the ZWZ to join the Peasants' Battalions (BCh). At the same time he became a member of the underground People's Party „Roch”. After the BCh where merged with the Home Army, he took command of the "Pająk” battalion. In 1943, he was promoted within the BCh and became commander of the Cracow district codenamed „Forest Inspectorate No. 6". Shortly after the liberation from the Germans, he answered the call of the new authorities to join the so-called Polish People's Army. Initially he was not sent to the front, eventually he was sent to the 2nd Army. He did not manage to take part in fights against the Germans. He was near Dresden, from where he was withdrawn through Wrocław to Rzeszów, where he took part in fights with the Ukrainian Insurgent Army. After being demobilized, he returned to his hometown.

Keywords: Jan Kotyza, Polish Underground State, Home Army, Peasants' Battalions, Peasant movement, Cracow district, World War II, underground work, Bieńczyce, Polish People's Army

\section{АННОТАЦИЯ}

\section{Войчех Падуховский, Ян Котыза - солдат Армии Крайовой, Крестьянских Батальонов и народного Войска Польского. Биографический очерк}

В статье представлен биографический очерк Яна Котызы, солдата Армии Крайовой, Крестьянских батальонов и народного Войска Польского.

Ян Котыза родился в Беньчице под Краковом, в крестьянской семье. Благодаря настойчивости родителей и учителей он окончил гимназию, а впоследствии учился по направлении „физическая культура” в Ягеллонском университете. Незадолго до начала Второй мировой войны Котыза занял должность управляющего недавно построенным муниципальным стадионом 
на улице Аллея 3 Мая в Кракове. Котыза был офицером запаса, но в Польской кампании 1939 г. участия не принимал. Во время оккупации он был задействован в конспиративных действиях, которые поначалу заключались только в распространении подпольной прессы. Он вступил Союз вооруженной борьбы (СВБ) принял псевдоним «Кшемень» („Кремень”). Первоначально он организовал взвод в деревнях Беньчице, Кшеславице и Мистшейовице. Затем он стал командиром поста СВБ „Могила”, который территориально охватывал три гмины: Могилу, Рушчу и Венгжце. Из Союза вооруженной борьбы Котыза перешел в Крестьянские Батальоны и одновременно с этим стал членом конспиративной Народной Партии „Рох”. После объединения Армии Крайовой и Крестьянских Батальонов он стал командовать батальоном „Пайонк” („Паук”). В 1943 г. в рамках Крестьянских Батальонов он получил повышение и стал комендантом краковского повята под криптонимом „Лесной округ №6”. Вскоре после освобождения от немцев он откликнулся на призыв новых властей присоединиться к народному Войску Польскому. Поначалу его не высылали на фронт, но затем все-таки отправили на фронт 2-ой армии Войска Польского. Котыза не успел принять участие в боях с Германией. Он был под Дрезденом, откуда был выведен через Вроцлав в Жешув, где принял участие в боях с УПА. После демобилизации вернулся на родину.

Ключевые слова: Ян Котыза, Польское подпольное государство, Армия Крайова, Крестьянские батальоны, Народное движение, краковский повят, Вторая мировая война, подпольное движение, Беньчице, народное Войско Польское 